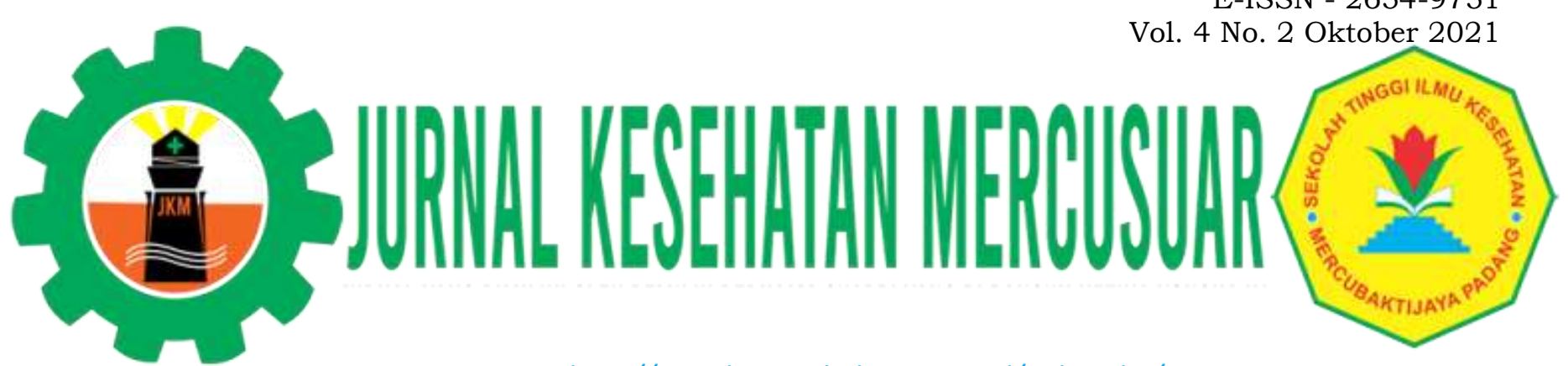

Avalilable Online http://jurnal.mercubaktijaya.ac.id/index.php/mercusuar

\title{
GAMBARAN KEBUGARAN JASMANI PADA LANJUT USIA
}

\author{
Dwi Purwantini ${ }^{*}$ \\ ${ }^{1}$ Prodi Fisioterapi, STIKES Katolik St. Vincentius a Paulo \\ *Email Korespondensi: dwiphysi@gmail.com
}

\begin{abstract}
Physical fitness is ability to carry out daily activities safely and effectively without experiencing significant fatique, and stikk having energy left to caary out leisure and recreational activities. The purpose of this study was determinethe description of physical fitness in the elderly. Research design with descriptive studied. The subjects of this study were elderly aged 60 year old in RW III Kelurahan Kebraon, Karang Pilang as many as 36 respondens. The sampling technique was purposive sampling. The data collected during the research were characteristic was gender, age, nutrisional status, physical activity, time physical activity and length of sitting. Sample characteristic data was colleted by filling out questionnaires and physical fitness was collected bay 2 minutes step test. Research data shows that 58,3\% have good physical fitness and 41,7 have poor physical fitness. The conclution from the study of elderly in RW III, kelurahan Kebraon, Karang Pilang, most of them have good physical fitness. Recommedation from this study were the importance of manintaining physical fitness who are still less fit, especially in the current pandemic condition by continuing to do physical activity to the dose.
\end{abstract}

Keywords: Physical fitness; Elderly; Physical activity

\begin{abstract}
ABSTRAK
Kebugaran jasmani adalah suatu kemampuan melakukan aktivitas keseharian dengan aman dan efektif tanpa mengalami kelelahan yang berarti, dan masih mempunyai sisa energi untuk melakukan aktivitas santai dan rekreasi. Tujuan penelitian ini untuk mengetahui gambaran kebugaran jasmani pada lanjut usia. Desain penelitian dengan studi deskriptif. Subyek penelitian ini adalah lansia umur $\geq 60$ tahun di RW III Kelurahan Kebraon, Kecamatan Karang Pilang sebanyak 36 responden. Teknik pengambilan sampling dengan purposive sampling. Data dikumpulkan saat pelaksanaan penelitian adalah data karakteristik yaitu jenis kelamin, usia, status gizi, aktivitas fisik, waktu/lama aktvitas fisik dan lama aktivitas duduk/diam. Data karakteristik sampel dikumpulkan dengan cara mengisi kuisioner dan data kebugaran jasmani dikumpulkan dengan 2 minutes step test. Data penelitian menunjukkan 58,3\% memiliki kebugaran jasmani baik dan 41,7 memiliki kebugaran kurang. Kesimpulan dari penelitian lanjut usia di RW III kelurahan Kebraon, Karang Pilang sebagian besar memiliki kebugaran jasmani yang baik. Saran dari penelitian ini adalah pentingnya tetap mempertahankan kebugaran jasmani pada lansia bagi yang sudah bugar dan meningkatkan kebugaran jasmani yang masih kurang bugar terutama dalam kondisi pandemi saat ini dengan tetap melakukan aktivitas fisik sesuai dengan dosis.
\end{abstract}

Kata Kunci: Kebugaran jasmani; Lanjut usia; Aktivitas fisik 


\section{PENDAHULUAN}

Lanjut usia (lansia) bukan suatu penyakit, namun merupakan tahap lanjut dari suatu proses kehidupan yang ditandai dengan penurunan kemampuan tubuh untuk beradaptasi dengan stress lingkungan. Penurunan kemampuan berbagai organ, fungsi, dan stres lingkungan itu bersifat alamiah/ fisiologis. Menurut Peraturan Pemerintah Republik Indonesia Nomor 43 tahun 2014, lanjut usia adalah seseorang yang telah mencapai usia 60 (enam puluh) tahun ke atas (Kemenkes.RI, 2014). Namun, timbulnya masalah kesehatan pada lansia dapat dimulai pada awal usia 50 tahunan atau mungkin pada usia 40 tahunan. Usia harapan hidup lansia di Indonesia mengalami peningkatan karena keberhasilan pembangunan di berbagai bidang terutama kesehatan (Kemenkes.RI, 2016). Penduduk lansia pada tahun 2045 diproyeksikan mencapai hampir seperlima dari total penduduk Indonesia (BPS, 2020). Peningkatan penduduk lansia di Indonesia menimbulkan dampak, salah satunya kebugaran jasmani.

Kebugaran jasmani adalah suatu kemampuan melakukan aktivitas keseharian dengan aman dan efektif tanpa mengalami kelelahan yang berarti, dan masih mempunyai sisa energi untuk melakukan aktivitas santai dan rekreasi (Hoeger et al., 2018). Menurut Afriwardi (2014) kebugaran jasmani adalah suatu keadaan ketika tubuh masih memiliki sisa tenaga untuk melakukan kegiatan-kegiatan ringan yang bersifat rekreasi atau hiburan setelah melakukan kegiatan/ aktivitas fisik rutin. Kebugaran jasmani merupakan salah satu komponen dalam mencapai suatu produktivitas yang baik. Penelitian yang dilakukan oleh Nugraheni (2013) menyatakan bahwa lansia yang memiliki kebugaran jasmani yang baik dapat melakukan aktivitas keseharian dengan baik, sebaliknya lansia dengan kebugaran kurang baik tidak dapat melakukan aktivitas sehari-hari dengan baik.

Kebugaran jasmani dipengaruhi beberapa faktor, salah satunya adalah aktivitas fisik. Aktivitas fisik merupakan gerakan tubuh yang dihasilkan oleh kontraksi otot skeletal yang membutuhkan energi dan menghasilkan manfaat kesehatan yang progresif (W. . Hoeger \& Hoeger, 2015). Aktivitas fisik penting dilakukan untuk mempertahankan kesehatan, juga pada lansia (Hoeger et al., 2018). Pada lansia aktifivitas fisik yang disarankan untuk meningkatkan kebugaran adalah aktivitas dengan tipe aerobic, latihan kekuatan, latihan keseimbangan dan fleksibitas (Nigg, 2014). Aktivitas tipe aerobic contohnya jalan, bersepeda, berkebun, membersihkan rumah, senam aerobic, menari, berenang dan sebagainya. Hal ini sejalan dengan penelitian yang dilakukan oleh (Syahruddin, 2020) bahwa senam aerobic yang dilakukan dengan rutin 3-5 kali per-minggu selama 30-60 menit dapat meningkatkan kebugaran pada lansia. Juga penelitian (Douka et al., 2019) bahwa menari tradisional dapat meningkatkan kebugaran jasmani.

Alat ukur yang dapat dipakai untuk menggambarkan kebugaran jasmani pada lansia 2 minutes step test (2MST). Test yang mudah digunakan dan dapat dipakai menggambarkan kebugaran jasmani (aerobic endurance) pada lanjut usia (Plácido et al., 2019). 2 minutes step test merupakan alat ukur yang valid, reproducible, sensitive, dapat ditoleransi untuk mengukur peningkatan kemampuan fungsional pada lanjut usia (Haas et al., 2017).

Pada orang dewasa dan lansia aktivitas fisik dapat menurunkan resiko kematian dini, serangan jantung, stroke, diabetes tipe 2, tekanan darah tinggi, sindrom metabolic, kanker usus dan payudara. Selain itu aktivitas fisik juga membantu mencegah peningkatan berat badan, dapat menurunkan 
berat badan dengan kombinasi diet, meningkatkan kebugaran cardiorespirasi dan muscular, mengurangi resiko jatuh, mengurangi depresi dan meningkatkan fungsi kognitif pada lansia (Hoeger et al., 2018).

Berdasarkan latar belakang dan permasalahan tersebut peneliti tertarik untuk mengetahui gambaran kebugaran jasmani pada lansia pada lansia di RW III Kelurahan Kebraon Kecamatan Karang Pilang Surabaya.

\section{METODE PENELITIAN}

Penelitian ini menggunakan desain penelitian deskriptif kuantatif yaitu desain yang bertujuan mendeskripsikan (memaparkan) gambaran kebugaran jasmani pada lanjut usia di RW III Kelurahan Kebraon Kecamatan Karang Pilang. Pelaksanaan penelitian dilakukan pada bulan Juni 2021. Sampel penelitian adalah lansia dengan usia $\geq 60$ tahun. Sample dipilih berdasarkan purposive sampling. Data karakteristik sample dikumpulkan dengan cara memberikan kuisioner dan data kebugaran jasmani dikumpulkan dengan melakukan 2 minutes step test (2 MST).

Alat-alat yang diperlukan untuk melakukan test adalah stopwatch, alat hitung, pita ukur/ meteran, dan tensi. Sebelum melakukan test beri titik pada paha partisipan separuh dari patella dan crista illiaca. Ukur dari titik tersebut sampai ke lantai dengan menggunakan pita ukur. Selanjutnya beri tanda pada dinding dengan menggunakan lakban atau spidol sampai garis tengah paha partisipan. Sebelum tes dilakukan pemeriksaan tensi dan nadi. Selanjutnya partisipan berdiri didepan atau samping tembok, setelah mendengarkan instruksi "mulai" partisipan berjalan di tempat, lutut diangkat setinggi titik yang sudah ditandai pada dinding. Hitung jumlah lutut kanan yang diangkat sampai level tembok yang ditandai, jika lutut tidak mengangkat dengan benar jangan dihitung. Beritahukan kepada partisipan untuk melanjutkan mengangkat dengan benar kedua lutut (hanya menghitung jumlah lutut kanan yang diangkat dengan benar) selama 2 menit. Selanjutnya hasil jumlah langkah akan di intepretasikan berdasarkan normal range 2MST untuk menentukan kebugaran jasmani pada lanjut usia.

\section{HASIL DAN PEMBAHASAN}

Data deskriptif yang diperoleh meliputi usia, jenis kelamin, indeks massa tubuh (IMT), aktivitas fisik, waktu untuk aktivitas dan aktivitas duduk. Gambaran karakteristik responden dapat dilihat pada tabel 1 .

Tabel 1. Karakteristik responden

\begin{tabular}{lcc}
\hline \multicolumn{1}{c}{ Variabel } & Frekuensi & Prosentase $(\%)$ \\
\hline Jenis Kelamin & 5 & \\
Laki-laki & 31 & 13,8 \\
Perempuan & & 86,2 \\
Usia & 27 & 75 \\
60-64 Tahun & 7 & 19,4 \\
65-69 Tahun & 2 & 5,6
\end{tabular}




\begin{tabular}{lcc}
\hline \multicolumn{1}{c}{ Variabel } & Frekuensi & Prosentase $(\%)$ \\
\hline Status gizi & 0 & 0 \\
Kurus & 25 & 69,4 \\
Normal & 9 & 25 \\
Gemuk & 2 & 5,6 \\
Obesitas & & \\
Aktivitas Fisik & & \\
Rutin 1-2 x/minggu & 17 & 47,2 \\
Rutin $\geq 3$ x/minggu & 15 & 41,7 \\
Setiap hari & 4 & 11,1 \\
Waktu untuk Aktivitas & & \\
fisik & 7 & 19,4 \\
$<30$ menit & 18 & 50 \\
30-60 menit & 11 & 30,6 \\
$>60$ menit & & \\
Aktivitas duduk (per-hari) & 19 & 52,7 \\
1-2 jam & 15 & 41,7 \\
3-4 jam & 2 & 5,6 \\
\hline 5 jam & &
\end{tabular}

Tabel 2. Distribusi frekuensi responden berdasarkan tingkat kebugaran jasmani pada lanjut usia di RW III, Kelurahan Kebraon, Kecamatan Karang Pilang

\begin{tabular}{lcccc}
\hline \multirow{2}{*}{ Karakeristik Responden } & \multicolumn{2}{c}{ Kebugaran Jasmani } & \multicolumn{2}{c}{ Prosentase (\%) } \\
\cline { 2 - 5 } & Baik & Kurang & Baik & Kurang \\
\hline Usia & 15 & 12 & 41,7 & 33,3 \\
60-64 Tahun & 5 & 2 & 13,8 & 5,6 \\
65-69 Tahun & 1 & 1 & 2,8 & 2,8 \\
70-74 tahun & & & & \\
Jenis kelamin & 2 & 3 & 5,6 & 8,3 \\
Laki-laki & 19 & 12 & 52,7 & 33,3 \\
Perempuan & 21 & 15 & 58,3 & 41,7 \\
\hline Total & & & & \\
\hline
\end{tabular}

Berdasarkan tabel 1 dari 36 orang responden sebagian besar $(86,2 \%)$ berjenis kelamin perempuan yaitu sebanyak 31 orang lansia, dengan usia didapatkan hasil sebagian besar (75\%) berusia 60-64 tahun yaitu sebanyak 27 orang lansia. Kemudian berdasarkan status gizi didapatkan sebagian besar $(69,4 \%)$ normal yaitu 25 orang lansia. Selanjutnya berdasarkan ativitas fisik sebagian besar $(47,2 \%)$ rutin melakukan aktivitas fisik 1-2x per-minggu yaitu 17 orang lanjut usia, dengan waktu aktivitas fisik sebagian besar (50\%) antar 30-60 menit setiap kali melakukan aktivitas/ latihan fisik. Berdasarkan tabel 2 dari 36 responden memilik nilai rata-rata sebesar $58,3 \%$ memiliki kebugaran yang baik yaitu sebanyak 21 orang lansia. Selanjutnya yang mempunyai kebugaran jasmani kurang 41,7\% yaitu sebanyak 15 orang lansia

Lanjut usia (lansia) bukan suatu penyakit, namun merupakan tahap lanjut dari suatu proses kehidupan yang ditandai dengan penurunan kemampuan tubuh untuk 
beradaptasi dengan stress lingkungan. Penurunan kemampuan berbagai organ, fungsi, dan stres lingkungan itu bersifat alamiah/ fisiologis. Seseorang yang normal pasti akan dapat menyesuaikan diri dalam memasuki usia lanjut (Martono \& Pranaka, 2015).

Kebugaran jasmani merupakan bagian dari kebugaran total. Kualitas hidup lanjut usia akan menjadi lebih baik apabila memiliki kebugaran jasmani yang baik, yang artinya mampu melakukan aktivitas keseharian dengan aman dan efektif tanpa mengalami kelelahan yang berarti, dan masih mempunyai sisa energi untuk melakukan aktivitas santai dan rekreasi (Hoeger et al., 2018).

Penelitian secara umum menunjukkan lebih banyak lansia yang memiliki kebugaran yang baik $(58,3 \%)$ dibandingkan dengan yang kurang baik. Pemahaman akan pentingnya aktivitas fisik untuk meningkatkan kebugaran pada lansia menyebabkan sebagian besar lansia mempunyai kebugaran jasmani baik. Selain mengikuti kegiatan senam aerobic low impac yang rutin diikuti setiap 1 minggu sekali beberapa lansia aktif melakukan aktivitas fisik lain seperti jalan pagi, berkebun, bersepeda yang dilakukan 35x/minggu bahkan ada yang setiap hari dengan waktu antara 30-60 menit. Latihan aerobic dengan intensitas moderat, dengan dosis 30 menit/ hari (atau total latihan setiap minggu paling tidak 150 menit) merupakan latihan yang sesuai untuk lanjut usia (Bushman, 2017). Hal ini sesuai dengan penelitian Syahruddin (2020) latihan atau aktivitas fisik yang disarankan bagi lansia adalah latihan aerobic intensitas sedang dan dengan target latihan 3-5x per-minggu dengan waktu latihan 30-60 menit. Program latihan yang disarankan bagi lansia yaitu latihan aerobic, latihan penguatan otot, latihan fleksibilitas dan juga latihan keseimbangan (Bushman, 2017). Selain meningkatkan kebugaran jasmani pada lansia, aktivitas fisik memberikan banyak keuntungan berkaitan dengan kondisi kronis, juga meningkatkan kualitas tidur yang baik dan fungsi kognitif (Bushman, 2017).

Sebagian lansia (41,7\%) memiliki kebugaran jasmani yang kurang. Beberapa faktor yang mempengaruhi kebugaran jasmani pada lansia, aktivitas fisik dengan intensitas yang tidak sesuai yaitu intensitas moderat (Syahruddin, 2020). Jenis kelamin laki-laki umumnya memiliki tingkat kebugaran jasmani yang melebihi perempuan. Hormon androgenik yang dimiliki laki-laki berpengaruh terhadap perkembangan otot sehingga otot laki-laki umumnya lebih kuat daripada otot perempuan (Afriwardi, 2011). Meskipun ada penelitian yang menyatakan pada lansia kebugaran berdasarkan pada gender antara laki-laki dan perempuan tidak beda (Hambali et al., 2019). Factor aktivitas fisik yang kurang, jenis kelamin dan usia usia mempunyai hubungan dengan kebugaran jasmani (Oktriani et al., 2020). Menurunnya kebugaran jasmani dapat menyebabkan penyakit hipokinetik dini (yang berhubungan dengan ketidakaktifan fisik) (Hoeger et al., 2018).

Sebagian besar lanjut usia di RW III aktif melakukan aktivitas rumah tangga sendiri, seperti menyapu, memasak, mencuci dan membersihkan rumah. Kebugaran jasmani juga berhubungan dengan kemampuan melakukan aktivitas keseharian tanpa mengalami kelelahan dan menurunkan resiko penyakit hipokinetik (yang berhubungan dengan ketidakaktifan fisik).kebugaran juga berhubungan dengan IMT, sebagian besar lanjut usia di RW III dengan IMT normal $(69,4 \%)$. Selain melakukan latihan dan aktivitas fisik sesuai dengan intensitas moderate, sebagian besar lansia di RW III banyak melakukan aktivitas bergerak dibandingkan duduk lama, sebagian besar melakukan aktivitas duduk 
saat menonton TV sekitar 1-2 jam per-hari $(52,7 \%)$. Banyak penelitian merekomendasikan mengurangi aktivitas duduk untuk meningkatkan kesehatan (ACSM, 2017). Waktu duduk yang panjang berhubungan dengan resiko tinggi kondisi jantung dan metabolic, meningkatkan lingkar pinggang, resisten insulin yang buruk dan perubahan level kolesterol "baik" (ACSM, 2017). Aktivitas fisik yang baik berhubungan dengan kejadian diabetes pada lansia (T. et al., 2020). Menjadi "aktif" adalah satu dari kebiasaan paling penting pada orang dari berbagai usia untuk meningkatkan kesehatan mereka. Bagi lanjut usia latihan menjadi penting untuk memastikan kualitas hidup dan kemandirian, latihan teratur akan meningkatkan imun (kekebalan), mengurangi kerpos tulang, meningkatkan gerkan dan keseimbangan, membantu kondisi psikologis dan menurunkan resiko penyakit (Bushman, 2017).

\section{SIMPULAN}

Dapat disimpulkan bahwa kebugaran jasmani pada lanjut usia di RW III Kelurahan Kebraon, Kecamatan Karang Pilang 58,3\% memiliki kebugaran jasmani yang baik dan $41,7 \%$ memiliki kebugaran jasmani kurang.

\section{UCAPAN TERIMAKASIH}

Penulis mengucapkan terimakasih kepada warga lanjut usia di RW III, Kelurahan Kebraon, Karang Pilang, civitas akademika STIKES Katolik St Vincentius a Paulo yang memberikan dukungan baik dalam bentuk moril dan material kepada peneliti.

\section{DAFTAR PUSTAKA}

Afriwardi. (2014). Ilmu Kedokteran OLahraga. Jakarta: EGC.

BPS. (2020). Statistik Penduduk Lanjut
Usia. In Statistik Penduduk Lanjut Usia. Badan Pusat Statistik.

Bushman, B. A. (2017). ACSM, Complete Guide to Fitness \& Health (Second edi). Human Kinetics.

Douka, S., Zilidou, V. I., Lilou, O., \& Manou, V. (2019). Traditional dance improves the physical fitness and wellbeing of the elderly. Frontiers in Aging Neuroscience, 11(APR), 1-9. https://doi.org/10.3389/fnagi.2019.0007 5

Haas, F., Sweeney, G., Pierre, A., Plusch, T., \& Whiteson, J. (2017). Validation of a 2 Minute Step Test for Assessing Functional Improvement. 71-81. https://doi.org/10.4236/ojtr.2017.52007

Hambali, R. M., Kusmaedi, N., \& Jajat, J. (2019). Tingkat Kebugaran Jasmani Lansia Dikaji Berdasarkan Tingkat Partisipasi dan Gender. Jurnal Keolahragaan, $\quad 5(2), \quad 1$. https://doi.org/10.25157/jkor.v5i2.2150 Hoeger, W. ., \& Hoeger, S. A. (2015). Fitness and Wellness (Eleventh e). Cengage Learning.

Hoeger WWK., Hoeger SA., Hoeger CI, Fawson AL.. (2018). Lifetime Physical Fitness and Wellness A Personalized Program (15th edition). Wadworth, Cengage Learning.

Kemenkes.RI. (2014). KEMENKES RI.pdf (pp. 1-2). pusdatin.kemkes.go.id

Kemenkes.RI. (2016). Situasi Lanjut Usia (Lansia) di Indonesia. InfoDatin, Pusat Data dan Informasi Kementerian Kesehatan RI.

Martono, H., \& Pranaka, K. (2015). Buku Ajar Boedhy-Darmojo, Geriatri (Ilmu Kesehatan Lanjut Usia) (B. Darmojo \& H. Martono (eds.); Edisi-5). Fakultas Kedokteran Universitas Indonesia.

Nigg, C. R. (2014). ACSM's Behavioral Aspek of Physical Activity and Exercise. Lippincortt Williams and Wilkins. 
Oktriani, S., Kusmaedi, N., Daniel Ray, H. R., \& Setiawan, A. (2020). Perbedaan Jenis Kelamin, Usia, dan Body Mass Index (BMI) Hubungannya dengan Kebugaran Jasmani Lanjut Usia. Jurnal Terapan Ilmu Keolahragaan, 5(1), 2840.

https://doi.org/10.17509/jtikor.v5i1.248 95

Plácido, J., Ferreira, J. V., Oliveira, F. De, Anna, P. S., Monteiro-junior, R. S., Laks, J., \& Deslandes, A. C. (2019). Association among 2-min step test, functional level and diagnosis of dementia. 13(1), 97-103.

Syahruddin, S. (2020). Kebugaran Jasmani Bagi Lansia Saat Pandemi Covid-19. JUARA : Jurnal Olahraga, 5(2), 232239.

https://doi.org/10.33222/juara.v5i2.943

T., E., Arini, L., \& Chantika, I. (2020). Hubungan Aktivitas Fisik Dan Kualitas Hidup Lansia Penderita Diabetes Mellitus Tipe 2. Jurnal Kesehatan Mercusuar, 3(2), 39-44. https://doi.org/10.36984/jkm.v3i2.132 